九州大学学術情報リポジトリ

Kyushu University Institutional Repository

\title{
Forest Product Industry and Current Problems of New Forest Owners in the Czech Republic
}

Macel, Premys l

Graduate School of Bioresource and Bioenvironmental Sciences, Kyushu Unviersity

Sato, Noriko

Faculty of Agriculture, Kyushu Unviersity

Ryuko, Hiroto

Faculty of Agriculture, Kyushu Unviersity

https://doi.org/10.5109/4685

出版情報: 九州大学大学院農学研究院紀要. 50 (2)，pp.753-766，2005-10-01. Faculty of Agriculture, Kyushu University

バージョン :

権利関係 : 


\title{
Forest Product Industry and Current Problems of New Forest Owners in the Czech Republic
}

\author{
Premysl MACEL ${ }^{1}$, Noriko SATO* and Hiroto RYUKOH
}

\author{
Laboratory of Forest Policy, Division of Forest Environment and Management Sciences, \\ Department of Forest and Forest Products Sciences, Graduate School of \\ Bioresource and Bioenvironmental Sciences, Faculty of Agriculture, \\ Kyushu University, Fukuoka, 812-8581 \\ (Received June 30, 2005 and accepted July 26, 2005)
}

\begin{abstract}
The general idea of the study is to address and explain the current process of establishing new economic relations in forestry-in-transition and assess opportunities for its sustainable development mainly by historical and political analyses approach. The scientific value of the study derives from the elaboration of multidisciplinary knowledge and the enhancement of practical applicability in a transitional economy of the concept of sustainable forestry development. Taking the forest sector of the Czech Republic as an example, the study draws on the state of affairs in forestry that is developing under changing economic conditions, examining failures and new incentives in economic and institutional reforms. The central objective of the study is to determine the appropriate forest policies and economic incentives to improve future output from Czech forestry, while making the sector economically efficient, socially acceptable and environmentally friendly. The way of the forest sector towards sustainable development is explored by analyzing the following: economics of forest use; contribution of forestry to country's economy; external trade and market in forest product; and issues affecting new forest owners, especially problems rising from the political and economic transition, and accession to the European Union.
\end{abstract}

\section{INTRODUCTION}

Czech Republic's forestry, by its nature and location is rurally based and conservative. The industries which it has spawned have become successful and powerful and dominate the Forest Industry, which in its traditional clothes can be said to have reached maturity. It supplies country's needs of wood products, it is an exporter and to some extent earner of foreign exchange, and is an employer on whom many people depend both directly and indirectly, although these numbers are recently decreasing. The era of an industry, conservative, self-sufficient and perhaps somewhat complacent has come to an end, however. It is to become part of the new Czech Republic, to recognize that there are other aspects of our national life, hitherto largely neglected, on which forestry impinges and on which forestry must in future have a positive effect. Forests, as a natural resource, have the unique characteristic that the principle product that is exploited economically itself creates the habitat for many of other species. A forest without trees is not a forest, but a

\footnotetext{
1 Laboratory of Forest Policy, Division of Forest Environment and Management Sciences, Department of Forest and Forest Products Sciences, Graduate School of Bioresource and Bioenvironmental Sciences, Faculty of Agriculture, Kyushu University

* Corresponding author (E-mail: sato@ffp.kyushu-u.ac.jp)
} 
lake without fish is still a lake. Therefore forest management involves a balancing between the economic benefits of resource exploitation and the environmental costs of resource depletion.

Systems for forest ownership and management in the world are very diverse. In Europe, public ownership (by region or district rather than the state) characterizes Germany and Switzerland, while farmers are the major forest owners in Scandinavia, Britain, Austria and the Mediterranean countries. The topic of forest policy related to private forests is of high importance in most countries today. Demand, supply and trade of forest products are a result of the interplay between at least the following four main factors:

1. The present setting of the forest sector (forests, forestry, forest industries).

2. Population and economic growth.

3. Technological change.

4. Policies and institutional aspects.

The overall purpose of the study is to analyse the developments of the Czech forest products industry and issues affecting new forest owners, especially problems rising from the political and economic transition, and accession to the European Union. The immediate objective is to revise the Czech forestry sector strategy so that it is consistent with and reflective of the needs of the forest owners, recent thinking and initiatives at different levels and developments in the sector. Also, possible approaches for the future will be identified.

\section{ECONOMIC CONDITIONS AND TRENDS IN CZECH FORESTRY}

\section{General outline}

As of December 31, 2000, CR had 10,266,546 inhabitants, making it a country with the 14th largest population in Europe. CR has medium population density in Europe, with an average population density of 131 inhabitants per $\mathrm{km}^{2}$. It is practically homogeneous in its nationality composition, as $95 \%$ of the population consists of Czech, Moravian and Silesian nationalities. However, since the beginning of the nineties, it has begun to be a country accepting a large number of immigrants, especially from southern and Eastern Europe and some Asian countries. The settlement structure consists in more than 15,000 mostly small settlements; almost half of them have less than 100 inhabitants and $93 \%$ have less than 1,000 inhabitants. Only seven cities have a population of over 100,000 people.

In 2001 the real GDP growth accelerated (while in 2000 the growth amounted to $2.9 \%$, in 2001 it was $3.6 \%$ ). This growth rate means that the Czech Republic is ranked 5th among 30 OECD member states. The negative balance of foreign trade slightly dropped. Forest has increasingly become the important factor of social economic development of society. Costs of the fulfillment of all social demands made on forest have to be covered to a large extent by returns on timber sales. As a result of decline in timber prices, reduction of roundwood supply as well as change in its structure in favour of less marketable broadleaved assortments, GDP in the forestry sector dropped by $6 \%$ in comparison with 2000.

Besides timber production, multifunctional forest management also fulfils a wide 
range of other ecological and social functions for the benefit of public. The making of methodology for assessment of those non-wood benefits is one of the important tasks of forest policy.

\section{Position of forestry in national economy}

The mission of forestry is to safeguard sustainable, and at the same time effective forest management. To meet this aim, it requires a responsible approach to forests, as a living entity, from both forest owners and business companies. Consequently, the purpose of business activities in forestry is not only achieving the measurable economic results, but also creating the enjoyable environment that influences people's health, their mood and mental balance.

The volume of forest production increases each year, while the number of employees working in this sector is steadily decreasing. The share of forestry in GDP is low (0.5\%), with a declining trend on a long-term basis. This indicator includes only marketable production in the sector. Forestry, however, ensures a wide range of irreplaceable social benefits which cannot be nominally quantified. The influence of forestry on employment and the direct existence of relating woodworking and pulp and paper sectors is not negligible, either.

The importance of forestry as a supplier of a renewable natural domestic raw material can be considerably increased by the coordinated action of the forestry and forest industry sectors. From the national economy view, exports of timber as raw material are not advantageous, and the aim must be concentrated on its processing and trading the final product. The basic prerequisite is the modernization of the woodworking industry mak-

Table 1. Selected economic indicators

\begin{tabular}{|c|c|c|c|c|}
\hline \multirow[t]{3}{*}{ Indicator } & \multicolumn{4}{|c|}{$\begin{array}{l}\text { Percentage change } \\
\text { compared to previous year }\end{array}$} \\
\hline & \multicolumn{2}{|c|}{ Actual } & \multicolumn{2}{|c|}{ Estimate } \\
\hline & 2000 & 2001 & 2002 & 2003 \\
\hline $\begin{array}{l}\text { Gross domestic product } \\
\text { (1995 constant prices) }\end{array}$ & 3.3 & 3.1 & 2.0 & $2.2-3.0$ \\
\hline $\begin{array}{l}\text { Industrial production } \\
\text { ( } 2000 \text { constant prices) }\end{array}$ & 5.4 & 6.8 & 4.8 & \\
\hline $\begin{array}{l}\text { Of which: } \\
\text { - woodworking industry }\end{array}$ & 15.0 & 5.3 & 6.1 & \\
\hline - pulp, paper and printing industry & 1.5 & 1.0 & 2.8 & \\
\hline $\begin{array}{l}\text { Construction } \\
\text { ( } 2000 \text { constant prices) }\end{array}$ & 5.3 & 9.6 & 2.5 & \\
\hline $\begin{array}{l}\text { External trade (FOB/FOB current prices) } \\
\text { of which: }\end{array}$ & 27.6 & 11.6 & -4.3 & \\
\hline $\begin{array}{l}\text { - Imports } \\
\text { - Exports }\end{array}$ & 23.4 & 13.2 & -1.4 & \\
\hline
\end{tabular}

Source: Ministry of Agriculture of the Czech Republic $(2000,2001,2002)$ 
ing it possible to add value to timber at both the domestic and European markets.

\section{External trade in forest products}

The development of the external trade was thus affected by number of new (administrative and economic) factors. The change in the trading conditions became evident in the first half of 2004 in the favourable development of the external trade, which was characterized especially by:

- High export and import growth rates which translated into reaching the record-breaking value of external trade turnover. In January to June, exports grew by $21.6 \%$ (CZK 145.5 billion) and imports by $20.2 \%$ (CZK 139.8 billion). External trade turnover thus increased by $20.9 \%$ and was CZK $1,650.2$ billion. In terms of the euro, exports increased by $18.4 \%$ and imports by $17.1 \%$, while in terms of the US dollar they increased by $31.2 \%$ and $29.7 \%$, respectively (all year-on-year);

- A slight lead of the growth rate of exports on the growth rate of imports. Imports still prevailed over exports, but the difference was diminishing. The CZK 11.7 billion external trade deficit was down by CZK 5.7 billion year-on-year;

- Changes in the territorial structure of the external trade. These were heavily influenced by the accession of the CR to the EU. In the first half of 2004, the EU-25 member states accounted for $86.8 \%$ of the total value of exports and for $73.9 \%$ of the total value of imports; the corresponding figures for the European transitive economies were $2.0 \%$ and $0.6 \%$, respectively;

- Movements in the commodity structure of the external trade. Imports increase year-on-year in all SITC sections;

- Different ways of collecting data and changes in the methodology and legislation before and after the accession of the CR to the EU - these considerably affected the external trade statistics. The data collection system for a prevailing part of the external trade changed in principle.

\section{DEVELOPMENT IN FOREST PRODUCTS MARKETS SECTORS}

\section{Wood raw material}

In 2003 , removals of wood raw material increased on the previous year by $4.1 \%$ to $15,140,000 \mathrm{~m}^{3}$. Production of industrial wood grew by $3.1 \%$ to $13,960,000 \mathrm{~m}^{3}$ and that of fuel wood increased by $17.1 \%$ to $1,180,000 \mathrm{~m}^{3}$. Softwood prevails $\left(90.2 \% ; 13,660,000 \mathrm{~m}^{3}\right)$ in the total production of wood raw material. Hardwoods account for $1,480,000 \mathrm{~m}^{3}$. The industrial wood amounting to $13,960,000 \mathrm{~m}^{3}$ includes $59.3 \%$ of sawlogs $\left(8,605,000 \mathrm{~m}^{3}\right)$ $33 \%$ of pulpwood $\left(4,965,000 \mathrm{~m}^{3}\right)$ and $2.7 \%$ of other wood. In 2003 , removals of coniferous sawlogs and veneer logs increased by $7.5 \%$ to $8,108,000 \mathrm{~m}^{3}$, imports dropped by $17.5 \%$ to $307,000 \mathrm{~m}^{3}$ and exports rose by $37.6 \%$ to $2,155,000 \mathrm{~m}^{3}$ year-on-year. As in the previous years, Austria was the main purchaser of coniferous sawlogs and veneer logs in 2003 . The Austrian market developed a high demand for first-rate coniferous roundwood in the second half of 2003. This situation in Austria arose as a result of violent windstorms between October 2002 and January 2003 as these left behind over 5 million $\mathrm{m}^{3}$ of breakage and the following extremely dry and hot summer when the breakage wood was attacked by pests. In response to the inquiry made in the Austrian market, deliveries of coniferous 
sawlogs and veneer logs from the Czech Republic were raised. A smaller proportion of these goods were exported to Germany.

In comparison with 2002 , removals of non-coniferous roundwood decreased in 2003 by $6.7 \%$ to $497,000 \mathrm{~m}^{3}$, imports grew by $42 \%$ to $121,000 \mathrm{~m}^{3}$, exports decreased by more than half to $27,000 \mathrm{~m}^{3}$, and consumption increased by $3.6 \%$ to $591,000 \mathrm{~m}^{3}$. In comparison with 2002 , removals of pulpwood decreased in 2003 by $2.3 \%$ to $4,965,000 \mathrm{~m}^{3}$ of which removals of coniferous pulpwood grew by $0.7 \%$ to $4,492,000 \mathrm{~m}^{3}$ and removals of non-coniferous pulpwood dropped by $23.8 \%$ to $473,000 \mathrm{~m}^{3}$. In the pulpwood trade, imports of coniferous pulpwood dropped by $60 \%$ to $162,000 \mathrm{~m}^{3}$. The coniferous pulpwood is imported by the pulp and paper industry for production of pulp; these imports have had a downward trend since 1998, as more and more of this material is used from domestic sources. The exports increased by $21.4 \%$ to $533,000 \mathrm{~m}^{3}$ and domestic consumption decreased a little. Imports of non-coniferous pulpwood have dropped to $7,000 \mathrm{~m}^{3}$ and exports increased by $3.6 \%$ to $240,000 \mathrm{~m}^{3}$. In trade with industrial roundwood, the year 2003 saw imports of the roundwood down by $40 \%$ at $597,000 \mathrm{~m}^{3}$ and exports up by $28.3 \%$ at $2,955,000 \mathrm{~m}^{3}$, compared to 2002 .

Table 2. Production (removals) of wood $\left(1000 \mathrm{~m}^{3}\right)$

\begin{tabular}{lrrrrrrr}
\hline & & \multicolumn{3}{c}{ Industrial roundwood } & Wood & Total \\
\cline { 3 - 7 } Product & Year & Total & $\begin{array}{c}\text { Sawlogs } \\
\text { Veneer } \\
\text { logs }\end{array}$ & Pulpwood & Other & $\begin{array}{c}\text { Woel } \\
\text { fuel }\end{array}$ & Total \\
\hline Total & 2002 & 13,534 & 8,073 & 5,081 & 380 & 1,007 & 14,541 \\
& 2003 & 13,687 & 8,067 & 5,230 & 390 & 1,030 & 14,717 \\
Of which: & 2004 & 13,810 & 8,120 & 5,300 & 390 & 1,035 & 14,845 \\
Non-coniferous & 2002 & 1,174 & 533 & 621 & 20 & 357 & 1,531 \\
& 2003 & 1,191 & 551 & 620 & 20 & 340 & 1,531 \\
& 2004 & 1,205 & 560 & 625 & 20 & 345 & 1,550 \\
\hline
\end{tabular}

Source: Ministry of Agriculture of the Czech Republic (2002, 2003, 2004)

\section{Wood energy}

Resolution of the Government of the Czech Republic No. 53 of 13 January 2003, on the National Forestry Programme includes in its programme measures the re-assessment of the possibility to contribute with deliveries of lower-quality wood and wood waste to energy purposes of the Czech Republic, as well as the assessment of preconditions and possibility to raise the production of wood by growing fast-growing tree species in a plantation way on agricultural land and on areas reclaimed after coal mining, supported in the framework of the National Programme on the Support of Energy Saving and the Use of Renewable Energy Sources.

\section{Certified forest products}

In the Czech Republic, the area of forests certified according to the Pan European Forest Certification (PEFC) totalled 1,909,747 ha, which is approximately $72 \%$ of the total forest area in the Czech Republic. At present, small municipalities and small forest 
owners in particular are getting involved in the forest certification. Along with the forest certification, certification of wood and pulp and paper products is under way in the consumer chain. By 31st December 2003, the companies were issued 59 individual and group certificates according to the PEFC system and 12 certificates according to Forest Stewardship Council (FSC) system.

\section{Value-added wood products}

In terms of value (CZK million $\mathrm{FOB} / \mathrm{FOB}$, current prices), trade in value-added wood products recorded (i) a drop of $6.1 \%$ to CZK 582 million for imports and an increase of $17.1 \%$ to CZK 883 million for exports in the assortment of further processed sawnwood, (ii) an increase of $19.6 \%$ to CZK 714 million for imports and an increase of $5.6 \%$ to CZK 2,456 million for exports in the assortment of wooden wrapping and packing equipment, (iii) an increase of $24.5 \%$ to CZK 1,789 million for imports and a decrease of $1 \%$ to CZK 3,886 million in the assortment of builder's joinery and carpentry of wood, and (iv) an increase of $18.1 \%$ to CZK 5391 million for imports and an increase of $0.4 \%$ to CZK 6,898 million for exports for the assortment of wooden furniture. The trade in these assortments of value-added wood products is expected to grow further in 2004 and 2005.

\section{Sawn softwood}

Production of sawn softwood in 2003 remained practically at its 2002 level - it increased slightly to $3,502,000 \mathrm{~m}^{3}$. In the sawn softwood trade, imports grew by $3.2 \%$ to $256,000 \mathrm{~m}^{3}$ and exports by $1.3 \%$ to $1,413,000 \mathrm{~m}^{3}$. Both export and import prices were generally higher. Domestic consumption was slightly lower, $2,345,000 \mathrm{~m}^{3}$ (all year-on-year). In 2003, sawn softwood was imported from Germany, Russian Federation and Slovakia and exported mainly, about $80 \%$, to European destinations (Austria, Germany and Great Britain) and overseas (the USA, Japan and Australia). In May 2004, a new sawmill of Mayr-Melnhof Holz GmBH was opened in the municipality of Paskov not far from the town of Ostrava. Production capacities: sawing 1 million $\mathrm{m}^{3}$ of coniferous roundwood in the final stage of construction, planning $250,000 \mathrm{~m}^{3}$ and drying $380,000 \mathrm{~m}^{3}$. Sawn softwood will be supplied to the domestic market and traditional markets in Europe and overseas.

A decrease in exports and an increase in imports of coniferous roundwood are expected in connection with ensuring raw material, coniferous roundwood, for this new production capacity. The estimate of sawn softwood production in 2004 accounts for the lowest variant: $3,600,000 \mathrm{~m}^{3}$ - i.e. an increase of $2.7 \%$ on the year 2003 , which is likely to be overcome. The raw material, coniferous roundwood, for the higher production of sawn softwood should be obtained by another reduction in exports of coniferous roundwood than it is given, i.e. $1,675,000 \mathrm{~m}^{3}$.

\section{Sawn hardwood}

Production of sawn hardwood in 2003 increased by $1 \%$ to $303,000 \mathrm{~m}^{3}$; imports decreased by $15 \%$ to $113,000 \mathrm{~m}^{3}$ and exports by $24 \%$ to $41,000 \mathrm{~m}^{3}$, and domestic consumption remained at its 2002 level $\left(375,000 \mathrm{~m}^{3}\right)$. Imports and consumption of tropic wood had increased by $100 \%$ to $6,000 \mathrm{~m}^{3}$ both. 
Table 3. Summary of different forest products $\left(1000 \mathrm{~m}^{3}\right)$

\begin{tabular}{|c|c|c|c|c|c|}
\hline Product & Year & Production & Imports & Exports & $\begin{array}{c}\text { Apparent } \\
\text { consumption }\end{array}$ \\
\hline \multirow{3}{*}{$\begin{array}{l}\text { Sawnwood, } \\
\text { coniferous }\end{array}$} & 2002 & 3,500 & 248 & 1,394 & 2,354 \\
\hline & 2003 & 3,535 & 230 & 1,420 & 2,345 \\
\hline & 2004 & 3,540 & 230 & 1,425 & 2,345 \\
\hline \multirow{3}{*}{$\begin{array}{l}\text { Sawnwood, } \\
\text { non-coniferous }\end{array}$} & 2002 & 300 & 133 & 54 & 379 \\
\hline & 2003 & 295 & 130 & 50 & 375 \\
\hline & 2004 & 295 & 130 & 50 & 375 \\
\hline \multirow{3}{*}{$\begin{array}{l}\text { Sawlogs and } \\
\text { veneer logs, } \\
\text { coniferous }\end{array}$} & 2002 & 7,540 & 372 & 1,566 & 6,346 \\
\hline & 2003 & 7,516 & 380 & 1,548 & 6,348 \\
\hline & 2004 & 7,560 & 382 & 1,540 & 6,402 \\
\hline \multirow{3}{*}{$\begin{array}{l}\text { Sawlogs and } \\
\text { veneer logs, } \\
\text { non-coniferous }\end{array}$} & 2002 & 533 & 85 & 48 & 570 \\
\hline & 2003 & 551 & 90 & 50 & 591 \\
\hline & 2004 & 560 & 95 & 55 & 600. \\
\hline \multirow{3}{*}{$\begin{array}{l}\text { Pulpwood } \\
\text { (round and split), } \\
\text { coniferous }\end{array}$} & 2002 & 4,460 & 412 & 439 & 4,433 \\
\hline & 2003 & 4,610 & 500 & 550 & 4,560 \\
\hline & 2004 & 4,675 & 500 & 560 & 4,615 \\
\hline \multirow{3}{*}{$\begin{array}{l}\text { Pulpwood } \\
\text { (round and split), } \\
\text { non-coniferous }\end{array}$} & 2002 & 621 & 121 & 249 & 493 \\
\hline & 2003 & 620 & 120 & 280 & 460 \\
\hline & 2004 & 625 & 110 & 280 & 455 \\
\hline \multirow[t]{3}{*}{ Veneer sheets } & 2002 & 14 & 24 & 18 & 20 \\
\hline & 2003 & 14 & 24 & 16 & 22 \\
\hline & 2004 & 15 & 24 & 17 & 22 \\
\hline \multirow[t]{3}{*}{ Plywood } & 2002 & 139 & 71 & 111 & 99 \\
\hline & 2003 & 145 & 70 & 115 & 100 \\
\hline & 2004 & 150 & 70 & 118 & 102 \\
\hline \multirow[t]{3}{*}{ Particle board } & 2002 & 874 & 256 & 502 & 628 \\
\hline & 2003 & 892 & 250 & 480 & 662 \\
\hline & 2004 & 910 & 250 & 490 & 670 \\
\hline \multirow[t]{3}{*}{ Fibreboard } & 2002 & 82 & 260 & 96 & 246 \\
\hline & 2003 & 84 & 260 & 98 & 246 \\
\hline & 2004 & 84 & 260 & 98 & 246 \\
\hline
\end{tabular}

Source: Ministry of Agriculture of the Czech Republic (2002, 2003, 2004)

\section{Veneer sheets}

In 2003 , production of veneer sheets increased by $21.4 \%$ to $17,000 \mathrm{~m}^{3}$, imports dropped from 24 to $21,000 \mathrm{~m}^{3}$ and exports and consumption remained at 2002 level, $18,000 \mathrm{~m}^{3}$ and $20,000 \mathrm{~m}^{3}$, respectively.

\section{Plywood}

Plywood saw a decline in 2003 compared to 2002 in production (by $8.6 \%$ to 
$\left.127,000 \mathrm{~m}^{3}\right)$, imports $\left(26.7 \%\right.$ to $\left.52,000 \mathrm{~m}^{3}\right)$, exports $\left(26.1 \%\right.$ to $\left.82,000 \mathrm{~m}^{3}\right)$ and consumption (only $2 \%$ to $97,000 \mathrm{~m}^{3}$ ). They were imported from Finland and other European countries and exported to Germany, Austria and Italy in particular. Based on the first half of 2004 data, production of plywood is expected to increase by $10.2 \%$ to $140,000 \mathrm{~m}^{3}$, imports by $1.9 \%$ to $53,000 \mathrm{~m}^{3}$, exports by $13.4 \%$ to $93,000 \mathrm{~m}^{3}$, and consumption by $3 \%$ to $100,000 \mathrm{~m}^{3}$ - all compared to 2003. Another year-on-year increase in production, exports and consumption should occur in 2005.

\section{Particle board}

Records made for particle board in 2003 show that the production increased by $27.3 \%$ to $1,113,000 \mathrm{~m}^{3}$, imports decreased by $16.5 \%$ to $214,000 \mathrm{~m}^{3}$, exports increased by $3.5 \%$ to $520,000 \mathrm{~m}^{3}$, and consumption increased by $28.5 \%$ to $807,000 \mathrm{~m}^{3}$ year-on-year. Production of particle board in 2003 is the figure of the Czech Statistical Office and includes all kinds of particle board according to the harmonized system, including particle board of other ligneous materials, not of wood (HS 441090) and data on surface treatment of purchased particle boards (with melamine resin HS 441032 or decorative laminate HS 441033). In the previous years, including 2002 , these data were not included in production of particle board from the point of view of monitoring the balance of wood substance.

The rising number of enterprises which purchase and surface particle board with melamine resin or decorative laminate makes the monitoring of the balance of wood substance difficult. In 2004 , the production should rise by $0.6 \%$ to $1,120,000 \mathrm{~m}^{3}$, imports should remain unchanged, and exports are expected to rise by $13.4 \%$ to $590,000 \mathrm{~m}^{3}$, compared to 2003. Consumption is expected to drop by $7.7 \%$ to $745,000 \mathrm{~m}^{3}$. The year 2005 should see a rather small increase in production, the same level of imports and a small increase in consumption in comparison with 2004.

\section{Fibreboard}

Of the assortment of fibreboard, only MDF board is manufactured. In 2003 the production grew by $7.3 \%$ to $88,000 \mathrm{~m}^{3}$ year-on-year. The entire fibreboard assortment hardboard, MDF board and insulating board - is both imported and exported. Total imports of fibreboard dropped by $13.8 \%$ to $224,000 \mathrm{~m}^{3}$, exports dropped by $15.7 \%$ to $81,000 \mathrm{~m}^{3}$, and a decrease was also recorded for consumption, by $6 \%$ to $231,000 \mathrm{~m}^{3}$. Fibreboard was imported mainly from Germany, Austria and Poland and its largest exports went mainly to Poland, Slovakia and Finland. In 2004, the production should rise by $1.1 \%$ to $89,000 \mathrm{~m}^{3}$, and no changes are expected in imports, exports and consumption. No changes are forecast in 2005 compared to 2004.

\section{Pulp and paper}

Production of wood pulp in 2003 grew by $2.3 \%$ year-on-year to 718,000 tonnes: Imports increased by $8.7 \%$ to 174,000 tonnes, over $80 \%$ of the imported quantity being bleached sulphate chemical pulp. Exports went up by $1.5 \%$ to 335,000 tonnes and bleached sulphate chemical pulp made up $70 \%$ of total quantity. Production of other pulp, i.e. of pulp from fibres other than wood and from recovered fibres, increased from 1,000 tonnes in 2002 to 3,000 tonnes. Consumption of paper recovered for pulp production grew by $1.8 \%$ to 386,000 tonnes, imports fell by $12 \%$ to 36,000 tonnes and exports 
rose by $6 \%$ to 140,000 tonnes.

Europe was the main destination for both imports and exports of wood pulp in 2003. Only $14 \%$ of imports was from overseas, especially from the USA and (a smaller part) from Canada. Exports to countries outside Europe (where Germany, Austria, Slovakia and Slovenia prevail), to Asia stood at about 4\%. Imports and export prices of wood pulp were lower than in 2002 . In the first half of 2004 , wood pulp production maintained its upward trend - it grew by $1.4 \%$. It is expected to rise by $1.4-2 \%$ over the whole 2004 and this trend should also be in 2005. Year-on-year increases in imports and exports of wood pulp in 2004 are expected at values as in 2002 and the same is expected for 2005 . In the assortment of paper and paperboard, the year 2003 saw the production increased by $5,7 \%$ to 920,000 tonnes; imports and exports grew by $22.8 \%$ to 823,000 tonnes and $19 \%$ to 681,000 tonnes, respectively. Traditionally, imports are higher than exports. Import and export prices of paper and paperboard were generally lower in 2003 than in the previous year. In 2004, 3-4\% year-on-year increases are expected in production, imports, exports and consumption, which should occur in 2005.

\section{Economic aspects of forest policy}

Forestry currently accounts for $0.5 \%$ of gross domestic product, and in the long run the percentage is declining. This percentage only applies to production realized on the market, especially timber, but does not cover public utility services, i.e. the non-productive functions of forests. It is these functions of forests, which cannot be imported or replaced by industrial production, that are increasingly requested by society, and pressure is being brought to bear on forest owners to expand and intensify them.

In the past, the state's industrial policy resulted in the destruction of forest stands on large surfaces of mountain slopes in border regions. The Government must be prepared to give considerable financial support to these regions, as forest owners cannot ensure the basic non-productive functions of forests with their own resources alone:

In recent years, forestry has been showing favourable economic results. The State supported forest management mainly with the aim of ensuring the non-productive functions of forests. The real value of funds earmarked for forest management has been undergoing continuous decrease. The main aim is to maintain the economic profitability of forest management.

\section{Timber market}

Exports of roundwood reached 3.0 million $\mathrm{m}^{3}$ and expanded by $239,000 \mathrm{~m}^{3}$ when compared with the previous year. Imports of roundwood fell by $134,000 \mathrm{~m}^{3}$ and were 1.1 million $\mathrm{m}^{3}$. Active balance of foreign trade in roundwood rose and amounted to CZK 3.0 billion. Proportion of exports to Austria and Germany was $95 \%$ of total exports, while roundwood imports from both countries amounted to $65 \%$.

\section{PROBLEMS OF NEW FOREST OWNERS}

\section{Species composition - still far from being self-sufficient and sustainable}

The species composition in forests of the Czech Republic is characterized by a large difference between the current, and the original natural species composition. This is due 
to a history of intensive management of the forests since the 18th century. In order to stabilize forest ecosystems, increase and sustain production, and secure other forest functions (such as ecological and social), it will be necessary to modify the species composition, and especially to increase the proportion of broadleaved species.

Projections of future developments in modifications of species composition, based on information about the natural and current species compositions of the forests, and their consequences, are needed for forest policy decision-makers.

Assuming constancy of climate, technology, and wood volumes harvested annually, and afforestation tasks, which cover an average area of 37;000 ha per year, the necessary change and reconstruction of species composition of the forest stands proposed by the Government will require 226 million seedlings a year, of which the conifers will make up 122 million and broadleaves 104 million seedlings. This afforestation will require $2,400 \mathrm{~kg}$ of seeds of spruce, $1,900 \mathrm{~kg}$ of seeds of pine, and $700 \mathrm{~kg}$ of seeds of larch. The average annual seed requirement for beech is $71,000 \mathrm{~kg}$, which is significantly higher than the stock of available beech seeds $(26,281 \mathrm{~kg})$ in the Seed Production Plant Tyniste nad Orlici.

The transition to a higher proportion of broadleaves, from 8,751 ha/year to 13,172 ha/year will require an additional 177 million CZK/year (3 million GBP). The average costs of forest regeneration will then rise from the current $56,300 \mathrm{CZK} / \mathrm{ha} / \mathrm{year}$ up to ca. $61,100 \mathrm{CZK} / \mathrm{ha} / \mathrm{year}$.

\section{Ownership patterns - new problems arising as a result of various policy changes in the past}

The development of forest ownership, especially private forests in the Czech Republic is impeded by their excessive fragmentation, restrictive forest management rules, restricted access to timber markets and limited resources of private owners. Forest restitution was undertaken to serve historic justice by returning forest properties to their former owners. The non-state forest ownership patterns in each of four analysed historical phases were as follows; in the first phase (1867-1918), the non-state forest ownership was very high and by 1910 counted for almost $100 \%$ of the country's forests. At the beginning of the second phase (1918-1948), the share of forests owned by individuals went up to $75 \%$ but the total for non-state forests slightly decreased. Then, two drastic changes directly resulting from the unstable political climate in Europe (and The Second World War) occurred: In 1938, the vast mountainous areas around Czech borders (German Sudeten) were ceded to Germany. As a reaction to that, the first major wave of property confiscation took place right after the World War II. About 1,080,000 ha of total private forest area were confiscated by means of the "Benes Decrees". During the third phase (1948-1989), the second large-scale wave of confiscations occurred. Citizens were deprived of almost all real property. So the non-state ownership decreased to only $4.2 \%$ in 1990. At the first stage of the fourth phase (1989-2005), the reverse process began. The Czech Republic has had the most significant change in ownership structure due to its restitution activities, with non-state ownership jumping from $4.2 \%$ in 1990 to $35.6 \%$ in 1997, with further restitution claims still pending.

However, the process of restitution has been carried out with little concern for sustainability and competitiveness of private forests. Restrictive forest management rules 
and increasing focus on environmental and social goals mean higher production costs at a time when public support for private forests is reduced. Fair market access also becomes a challenge in regions dominated by large industries on the demand side and state forests on the supply side, or regions with poorly developed markets making timber sales at competitive prices difficult. Finally, market-based based initiatives such as certification are becoming increasingly common and may discriminate against small forest owners. Since forest owners are poorly organized, they loose the ability to exert more market power and trade in larger volumes through joint marketing.

While excessive fragmentation of private forests justifies government efforts supporting their consolidation, it is apparent that the minimum efficient scale of forest operations is currently unknown. These efforts will become more meaningful after determining how big a forest cooperative has to be in order to benefit from scale economies. It may be possible that in the current regulatory environment, private forest organizations need to approach the size of large state forest estate or industrial forests in order to reap any significant benefits, although this is unlikely. But on the other hand, even today large state forest estates are experiencing problems in remaining profitable.

\section{Economics of newly developed private forests}

Forest income is essential for private owners and their ability and willingness to invest into the management of their forests. Yet, it is clear that Czech forest management rules have little in common with profitability and economic efficiency. To improve private forest management, these rules must be revised. It is surprising that while entire forest policies have been rewritten to give them environmental focus, technical management rules determining harvest levels and silvicultural treatments were left with little attention. These rules make timber growing unprofitable in both private and state forests, putting in serious doubt the long-term competitiveness of the sector and the provision of environmental and social benefits, which are frequently financed by timber revenues. Well-targeted government assistance may alleviate some of these problems, but will not suffice without making substantial forest management changes.

The foregoing has pointed to a number of issues with important policy implications. One concerns the need to adapt management and silviculture to the changing pattern of demands by society on the forest, notably the increasing emphasis on the environmental and social functions, and the actual or potential impact on the "traditional" wood supply function. The Czech Republic is mostly densely populated and largely urbanized and has high standards of living; its needs for benefits from the countryside are increasingly diverse, both material and other. Forest industries will continue to depend on roundwood supplies from the forest. However, industry will increasingly use other raw materials, such as waste paper and industrial residues. It will be a major challenge to maintain the economic viability of the forest sector, while at the same time ensuring that it provides

Table 4. Ownership structure - forest owners by the size of their holdings

\begin{tabular}{ccccccc}
\hline Area [ha] & $0-1.0$ & $>1.0-2.0$ & $>2.0-5.0$ & $>5.0-10.0$ & $>10.0-50.0$ & $>50.0$ \\
\hline \% of owners & 77.1 & 11.6 & 8.2 & 2.0 & 0.8 & 0.3 \\
\hline Source: Ministry of Agriculture of the Czech Republic (2002) & &
\end{tabular}


the non-market goods and services that are increasingly in demand.

\section{POSSIBLE APPROACHES FOR THE FUTURE}

One approach that may work would be to rely on market forces in forests managed primarily for timber. Market prices can be viewed as tools providing information about resource scarcity that invoke appropriate market and investment responses. For its approach to work, some management regulations need to be relaxed. This requirement applies particularly to rotation length. Allowing for shorter rotations may help to stimulate private investment. In private forests, which fulfill important environmental functions, this approach is less likely to work, especially if forests provide benefits that the owners cannot capture. Such benefits may include wildlife habitat, watershed soil conservation, and recreational and aesthetic values. These benefits may actually be a good reason for providing subsidies and incentives such as various easement programmes. If owners are not interested in management of forests that yield substantial environmental benefits, then buy-outs may be offered.

The policy process needs to recognize that private forests differ from state forests in many aspects, including their size and management objectives. Policy makers need to decide what the role of state forests is and what the role of private forests is. Private forest owners have to be a part of the process. Policy makers need to determine what is feasible and desirable in private forests. They should clearly recognize that the behavior of private owners who do not follow current regulations is caused not by their perceived greed or irresponsibility but by the lack of other options. If a firm cannot generate sufficient revenues from its operations, it goes out of business; if a private owner is unable to follow management rules because of insufficient forest income, then that owner stops carrying out those operations. If owners are expected to address environmental goals, then some compensation for them needs to be considered. But then we do not know how real the non-timber benefits from small private forests are. The situation of private forests also needs to be considered in the development of international agreements, standards and policies to make sure, that private interests are represented and that private forests can also benefit from them.

Reforms of forests policy and ownership structure in the Czech Republic represent an enormous task. The range of policy options and tools available is impressive. Yet very few studies exist which analyse benefits, cost and effectiveness of various policy instruments. We know little about changes that are most appropriate and the extent to which they need to be carried out in order to achieve policy goals. Low profitability of forest production is automatically justified by ecological benefits, whose extent is often unknown. It is yet to be clearly defined what sustainability or biodiversity protection means for a small private forest. New SFM dimensions present new challenges to the management of small private forests and require new regulatory and planning approaches, as well as a much better understanding of economic, social and environmental dimensions of SFM principles. At present, nearly all efforts are devoted to ecological goals of forest management. The Czech Republic's experiences with private forests indicate that such a focus is probably too narrow and even counterproductive. Competitive pressures will continue to mount and it will be increasingly difficult to sustain viable 
forest operations. It is time to recognize that economic viability is also a necessary condition for making SFM a true success.

\section{CONCLUSION}

\section{Main problems in forest sector}

Among the main problems discovered are the biodiversity losses due to the industrial pollution. In fact, about $60 \%$ of forests are damaged on certain level. Also, high numbers of high deer in forests are causing severe damage to new plantations. Due to the significant change of tree species composition in the forests caused by various human activities, many forest stands are unstable. Main problems from the economical point of view are the high number of new small forest owners and drop in prices on timber market.

\section{Areas where improvements are needed}

- Fragmentation of forest land

- Forest legislation

- Forest conditions

- Education and public relations

- Lack of public involvement in forestry

- State supervising role during the transition period

\section{Problems of private owners}

Many of the forest owners have low level of management skills. There is a lack of cooperation among the owners. Most of them are only partly organized. Split distribution and inefficient size of forest units makes it almost impossible to earn profit from forest management. Large-scale forestry operations are considerably limited. Harvesting operations are often poorly planned, improperly implemented and inadequately supervised. Contemporary costs for training of new employees became too expensive.

\section{Problems characteristic for small owners}

Many of the small forest owners are not showing much interest and concern about their forests and some of them have no idea where their forests actually are located. This is mainly due to the fact that many of the owners live in the towns and cities far away from their holdings. Some of them are already old and become the victims of dishonest, profit-seeking people who offer them providing of services or a purchase of their forest holdings. The smallest holdings are not usually managed in proper way because of low skills, knowledge and sometimes also lack of interest.

\section{Some of the important tasks for future}

- Creation of forest co-operatives (with economic tools)

- Increasing knowledge and skills of private forest owners

- Raising awareness by accessing and sharing information

- Improving the image and public acceptance

- Building synergy among stakeholders

- Prepare institutional framework to meet the needs of forest owners 
- Empowering forest owners in decision making

- Improving the relation between the state forest services and authorities and the private forest owners

- More meaningful projection of the importance of forests into the national economy

- Valuation of non-timber benefits and services

- Support to private forest owners

- Improvement of public awareness and image of forestry

\section{REFERENCES}

Zprava o stavu lesa a lesniho hospodarstvi Ceske republiky (2000) Ministerstvo zemedelstvi CR, Praha, Zprava o stavu lesa a lesniho hospodarstvi Ceske republiky (2001) Ministerstvo zemedelstvi CR, Praha, Zprava o stavu lesa a lesniho hospodarstvi Ceske republiky (2002) Ministerstvo zemedelstvi CR, Praha, Zprava o stavu lesa a lesniho hospodarstvi Ceske republiky (2003) Ministerstvo zemedelstvi CR, Praha, Zprava o stavu lesa a lesniho hospodarstvi Ceske republiky (2004) Ministerstvo zemedelstvi CR, Praha, 